\title{
Bank stability and toe erosion model of the Kodku Khola bank, southeast Kathmandu valley, central Nepal
}

\author{
*Ishwor Thapa and Naresh Kazi Tamrakar \\ Central Department of Geology, Tribhuvan University, Kathmandu, Nepal \\ (*Email: ishworthapa1522@gmail.com)
}

\begin{abstract}
The Kodku Khola is a potential river from the southeast part of Kathmandu valley as it has been used for irrigation and household purposes from prehistoric time. The river is suffering from streambank instability causing great threat to the infrastructure, land and settlement areas. In this context, assessment of Bank Stability and Toe Erosion Model (BSTEM) of the Kodku Khola was undertaken for eight different sites using the BSTEM version 5.4 that calculates a Factor of Safety $\left(\mathrm{F}_{\mathrm{s}}\right)$ for multilayer streambank, based on limit equilibrium-method. Streambank of the uppermost reach around the transects BK1 (Lower Badikhel) and BK2 (Upper Taukhel) area is stable, where $\mathrm{F}_{\mathrm{s}}$ exceeds 1.3 and maximum lateral retreat of channel is $21.86-30.59 \mathrm{~cm}$ with $0.025-0.290$ $\mathrm{m}^{2}$ of the total eroded area of the bank-toe resulting in less bank toe erosion. Canopy and understorey cover with consolidated bank materials are the causes of stable banks. Streambank of transects BK3 (Arubot) and BK4 (Thaiba) are unstable as Fs ranges from 0.75 to 0.92 , and the maximum lateral retreat of channel ranges $70.83-208.81 \mathrm{~cm}$ with total eroded bank toe area of $0.117-1.695$ $\mathrm{m}^{2}$ resulting in excessive bank toe erosion problems. Major causes of instability are the presence of unconsolidated bank material, high scouring, and sparse riparian vegetation. Within the transects BK6 and BK7 around Harisiddhi, streambanks are stable with less bank toe erosion hazard because of channelization. Where the Fs are low and banks are disturbed by encroachment, suitable bioengineering measures can be implemented to mitigate excessive bank toe erosion and failure.
\end{abstract}

Keywords: Kodku Khola, BSTEM, factor of safety, maximum lateral retreat, streambank erosion

Paper Received: 08 May 2015

Paper Accepted: 29 January 2016

\section{INTRODUCTION}

The Kodku Khola is a potential and historical river from the southeast part of the Kathmandu valley (Fig. 1). It is the major tributary of the Manahara River and water of the Kodku Khola has been used for irrigation and household purposes from prehistoric time. It has a typical source of metasedimentary terrain dominantly of limestone of the Phulchoki Group (Stocklin 1980). The detailed stratigraphic study of the Kathmandu basin sediments consisting basically of gravel, silt and sand of fluvio-lacustrine deposit was conducted by Yoshida and Igarashi (1984) on the basis of surface geological mapping and paleomagnetic studies.

The Kodku Khola has been subjected to lateral and vertical instability and erosion hazards (Bajracharya et al. 2013). Streambank erosion is the significant land degradation process that creates vertical and lateral instabilities within the river valley. Human encroachment, tectonics, geotechnical properties of bank materials and hydro-meteorological events are the main factors of bank instability and bank-toe erosion hazard in the alluvial rivers. Streambank erosion causes hydraulic forces acting on bank surface and the failure of bank due to geotechnical instability of the bank are the most commonly observed bank erosion phenomenon in nature (Duan 2005).

The stream bank becomes unstable when driving force exceeds the resisting force. Bank resistance force is attributed

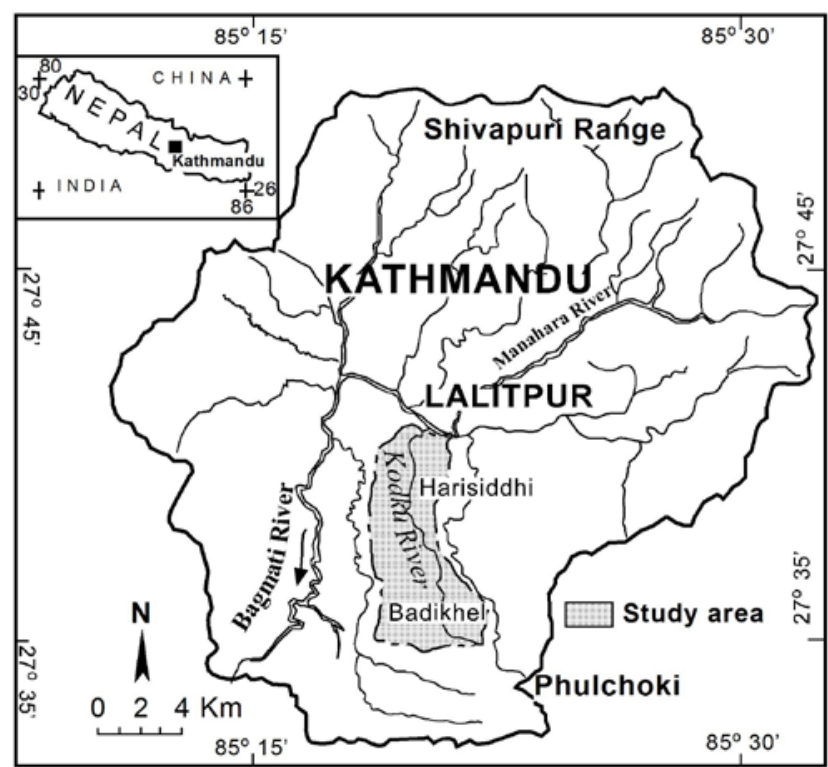

Fig. 1: Location map of study area.

by bank material soundness, bank angle, bank height, bank vegetation, degree of saturation. Because bank resistance force varies with the degree of saturation of bank material, the probability of bank failure is the probability of the driving force of bank failure being greater than the resistance force (Simon et al. 2011). For the bank stability analysis and toe 
erosion scenario the Bank Stability and Toe Erosion Model (BSTEM version 5.4) developed by scientists of USDA-ARS National Sedimentation Laboratory (original one by Simon et al. 1999, 2000) was adopted. The BSTEM calculates a factor of safety (Fs) for multilayer streambank, based on limit equilibrium-method. The streambank will be unstable when Fs is less than 1, conditionally stable when Fs is (1-1.3) and stable when Fs is greater than 1.3 (Simon et al. 2011). Hence, streambank stability and toe erosion scenarios are the crucial aspect while mitigating the hydraulic erosion and geotechnical instability in the alluvial rivers. The natural state of the Kodku Khola is disturbed due to bank erosion, mining of construction materials, human encroachment, deposing of municipal and industrial wastes and artificial modification of channel (Bajracharya et al. 2013). The river is also affected by bank erosion and instability problems by changing land use pattern and anthropogenic activities. Tamrakar et al. (2013) studied the morpho-hydrologic parameters and classification of the Kodku Khola and classified it as a fifth order stream with sinuous pattern, extending for about $15.86 \mathrm{~km}$ and its watershed covering an area of $35.67 \mathrm{~km}^{2}$ (Fig. 1). It has wide floodplains with narrow channel belt. This river is serving irrigation facilities to the fertile floodplain and terraces and drinking water for villagers within the watershed. But the river is degrading due to unplanned urbanisation and human encroachment. It may pose serious problems to environment, human health, ecosystem and natural flow of river unless mitigation measures are adopted. Hence, it is necessary to know the stream bank stability condition and bank toe erosion scenario of the river during the implementation of the stream restoration and management techniques.

\section{MATERIALS AND METHODS}

The Bank Stability and Toe Erosion Model (BSTEM) is a spreadsheet tool used to simulate stream bank erosion in a mechanistic framework. It has been successfully used in a range of alluvial environments in both static mode to simulate bank stability conditions and design of streambank stabilisation measures and iteratively over a series of hydrographs to evaluate surficial, hydraulic erosion, bank failure frequency, and the volume of sediment eroded from a bank over a given time period (Simon et al. 2011). It is programmed in Visual Basic and exists in the Microsoft Excel environment as a simple spreadsheet tool. The BSTEM Input-parameter values can all be obtained directly from field surveying and testing. If this is not possible, the model provides default values by material type for many parameters. Required data fall into three broad categories: (1) bank geometry and stratigraphy, (2) hydraulic data, and (3) geotechnical data. A summary of the required input parameters is provided in Table 1 . The default geotechnical values that are included in the model are provided in Table 2.

Table 1: Required user-input parameters for BSTEM (after Simon et al. 2011).

\begin{tabular}{|c|c|c|c|c|c|}
\hline & \multicolumn{2}{|c|}{ Driving Force } & & \multicolumn{2}{|c|}{ Resisting Force } \\
\hline Parameters & Purpose & Source & Parameters & Purpose & Source \\
\hline \multicolumn{6}{|c|}{ Hydraulic Processes: Bank Surface } \\
\hline $\begin{array}{l}\text { Channel } \\
\text { slope }(\mathrm{S})\end{array}$ & $\begin{array}{l}\text { boundary shear } \\
\text { stress }\left(\tau_{\mathrm{o}}\right)\end{array}$ & $\begin{array}{l}\text { field survey or } \\
\text { design plan }\end{array}$ & $\begin{array}{l}\text { particle diameter (D) } \\
\text { (cohesionless) }\end{array}$ & $\begin{array}{l}\text { critical shear } \\
\text { stress }\left(\tau_{c}\right)\end{array}$ & $\begin{array}{l}\text { bulk sample particle size } \\
\text { (cohesionless); default } \\
\text { values in model }\end{array}$ \\
\hline Flow depth (h) & $\begin{array}{l}\text { boundary shear } \\
\text { stress }\left(\tau_{\mathrm{o}}\right)\end{array}$ & $\begin{array}{l}\text { field survey, } \\
\text { gauge information, } \\
\text { design plan }\end{array}$ & $\begin{array}{l}\text { critical shear stress } \\
(\tau c)(\text { cohesive) }\end{array}$ & $\begin{array}{l}\text { critical shear } \\
\text { stress }\left(\tau_{c}\right)\end{array}$ & $\begin{array}{l}\text { jet test (cohesive); } \\
\text { default values in model }\end{array}$ \\
\hline $\begin{array}{l}\text { Unit weight } \\
\text { of water }\left(\gamma_{\mathrm{w}}\right)\end{array}$ & $\begin{array}{l}\text { boundary shear } \\
\text { stress }\left(\tau_{\mathrm{o}}\right)\end{array}$ & $\begin{array}{l}\text { considered } \\
\text { constant, } 9810 \mathrm{~N} \mathrm{~m}^{-3}\end{array}$ & $\begin{array}{l}\text { particle diameter (D) } \\
\text { (cohesionless) }\end{array}$ & $\begin{array}{l}\text { erodibility } \\
\text { coefficient }(\mathrm{k})\end{array}$ & $\begin{array}{l}\text { bulk sample particle size } \\
\text { (cohesionless); default } \\
\text { values in model }\end{array}$ \\
\hline & & & $\begin{array}{l}\text { critical shear stress } \\
\left(\tau_{c}\right) \text { (cohesive) }\end{array}$ & $\begin{array}{l}\text { erodibility } \\
\text { coefficient }(\mathrm{k})\end{array}$ & $\begin{array}{l}\text { jet test (cohesive); } \\
\text { default values in model }\end{array}$ \\
\hline \multicolumn{6}{|c|}{ Geotechnical Processes: bank Mass } \\
\hline $\begin{array}{l}\text { Unit weight of } \\
\operatorname{sediment}\left(\gamma_{\mathrm{s}}\right)\end{array}$ & $\begin{array}{l}\text { Weight }(\mathrm{W}) \\
\text { Normal force }(\sigma)\end{array}$ & \multirow{2}{*}{$\begin{array}{l}\text { core sample in } \\
\text { bank unit; default } \\
\text { values in model } \\
\text { field survey or } \\
\text { design plan }\end{array}$} & $\begin{array}{l}\text { Unit weight of } \\
\text { sediment }\left(\gamma_{\mathrm{s}}\right)\end{array}$ & $\begin{array}{l}\text { Weight }(W), \\
\text { Normal } \\
\text { force }(\sigma)\end{array}$ & $\begin{array}{l}\text { core sample in bank unit; } \\
\text { default values in model }\end{array}$ \\
\hline $\begin{array}{l}\text { Bank height } \\
(\mathrm{H})\end{array}$ & Shear stress & & $\begin{array}{l}\text { effective cohesion } \\
\left(c^{\prime}\right)\end{array}$ & $\begin{array}{l}\text { shear strength } \\
\left(\tau_{\mathrm{f}}\right)\end{array}$ & $\begin{array}{l}\text { borehole shear, } \\
\text { direct shear, triaxial shear; } \\
\text { default values in model }\end{array}$ \\
\hline \multirow{2}{*}{$\begin{array}{l}\text { Bank angle } \\
(\alpha)\end{array}$} & \multirow[t]{2}{*}{ Shear stress } & \multirow{2}{*}{$\begin{array}{l}\text { field survey or } \\
\text { design plan }\end{array}$} & $\begin{array}{l}\text { effective friction } \\
\text { angle }\left(\varphi^{\prime}\right)\end{array}$ & $\begin{array}{l}\text { shear strength } \\
\left(\tau_{\mathrm{f}}\right)\end{array}$ & \\
\hline & & & $\begin{array}{l}\text { pore water pressure } \\
\left(\mu_{\mathrm{w}}\right)\end{array}$ & $\begin{array}{l}\text { Shear strength } \\
\left(\tau_{\mathrm{f}}\right)\end{array}$ & $\begin{array}{l}\text { interpolated from water } \\
\text { table }\end{array}$ \\
\hline
\end{tabular}


Table 2: default Values in BSTEM for geotechnical properties $^{\mathrm{a}}$.

\begin{tabular}{|l|l|l|l|l|}
\hline \multicolumn{1}{|c|}{ Soil Type } & \multicolumn{1}{c|}{ Statistic } & $\mathbf{c}^{\prime}(\mathbf{k P a})$ & $\boldsymbol{\varphi}\left(^{\circ}\right)$ & $\boldsymbol{\gamma}_{\text {sat }}\left(\mathbf{k N m}^{\mathbf{3}}\right.$ \\
\hline Gravel (uniform)b & & 0.0 & 36.0 & 20.0 \\
\hline Sand and gravel & & 0.0 & 47.0 & 21.0 \\
\hline Sand & 75th percentile & 1.0 & 32.3 & 19.1 \\
\hline & Median & $\mathbf{0 . 4}$ & $\mathbf{3 0 . 3}$ & $\mathbf{1 8 . 5}$ \\
\hline & 25th percentile & 0.0 & 25.7 & 17.9 \\
\hline Loam & 75th percentile & 8.3 & 29.9 & 19.2 \\
\hline & Median & $\mathbf{4 . 3}$ & $\mathbf{2 6 . 6}$ & $\mathbf{1 8 . 0}$ \\
\hline & 25th percentile & 2.2 & 16.7 & 17.4 \\
\hline Clay & 75th percentile & 12.6 & 26.4 & 18.3 \\
\hline & Median & $\mathbf{8 . 2}$ & $\mathbf{2 1 . 1}$ & $\mathbf{1 7 . 7}$ \\
\hline & 25th percentile & 3.7 & 11.4 & 16.9 \\
\hline
\end{tabular}

${ }^{a}$ Data derived from more than 800 in situ direct-shear tests with the Iowa Borehole. Shear Tester except where indicated. BSTEM values are indicated in bold.

${ }^{b}$ Data from Hoek and Bray (1981).

Eight transacts (Fig. 2) along the Kodku Khola bank were selected for the determination of the BSTEM based on stream characteristics, bank geometry, bank material type, topography, vegetation and accessibility.

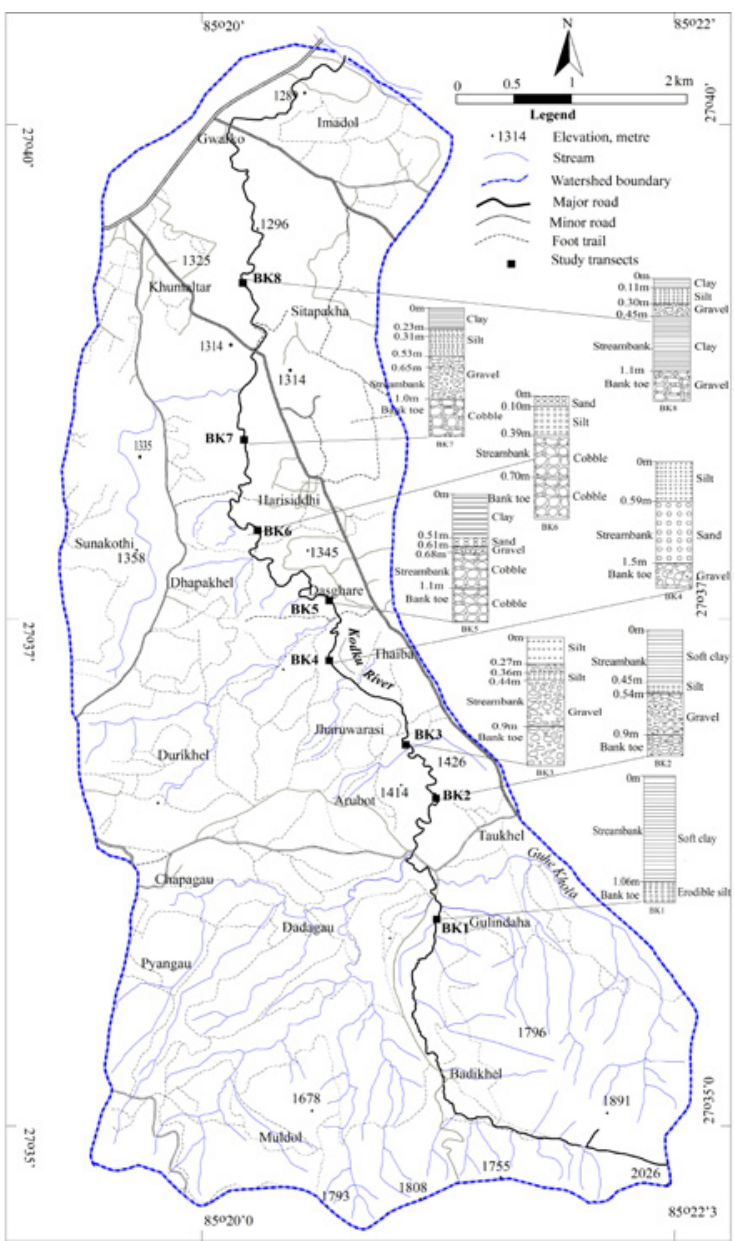

Fig. 2: Eight study transects and bank materials of the Kodku Khola.
The bank material types and properties were assessed for all eight studies transects (Fig. 2) which contributes the major input parameters in BSTEM. The BSTEM parameters as indicated by Simon et al. (2011) were calculated and determined from the field using Ushikata Theodolite Model S-25, staffs and a measuring tape. The study transects extends from lower Badikhel at upstream segment to upper Imadol at downstream segment of the Kodku Khola. All the parameters taken from field investigations assumed bankfull condition and water surface level is equal to ground water level throughout the study. Input parameters bank geometry, channel flow and boundary shear stress (Table 3 ) and geotechnical data (Table 4) used in the bank stability analysis and bank toe erosion modeling were taken from (Fredlund and Rahardjo. 1993 Hanson and Simon 2001) and from field investigation.

Table 3: Input parameters for eight transects of the Kodku Khola.

\begin{tabular}{|c|c|c|c|c|c|c|c|c|}
\hline Transects & BK 1 & BK2 & BK3 & BK4 & BK5 & BK6 & BK7 & BK8 \\
\hline \multicolumn{9}{|c|}{ Input parameters } \\
\hline $\begin{array}{l}\text { Input bank } \\
\text { height (m) }\end{array}$ & 1.10 & 0.90 & 0.90 & 1.50 & 1.10 & 0.70 & 1.00 & 1.10 \\
\hline $\begin{array}{l}\text { Input bank } \\
\text { angle }\left({ }^{\circ}\right)\end{array}$ & 86.00 & 82.00 & 85.00 & 87.00 & 84.00 & 86.00 & 80.00 & 80.00 \\
\hline $\begin{array}{l}\text { Input bank } \\
\text { toe } \\
\text { length }(\mathrm{m})\end{array}$ & 1.10 & 1.50 & 2.10 & 1.90 & 2.60 & 2.90 & 3.00 & 2.30 \\
\hline $\begin{array}{l}\text { Input bank } \\
\text { toe } \\
\text { angle }\left(^{\circ}\right)\end{array}$ & 12.00 & 7.00 & 11.00 & 11.00 & 9.00 & 8.00 & 8.00 & 9.00 \\
\hline $\begin{array}{l}\text { Input shear } \\
\text { surface } \\
\text { angle }\left(^{\circ}\right) \\
\end{array}$ & 44.70 & 58.20 & 83.00 & 85.00 & 82.00 & 84.00 & 78.00 & 78.00 \\
\hline No. of layers & 1.00 & 4.00 & 4.00 & 2.00 & 4.00 & 5.00 & 5.00 & 4.00 \\
\hline $\begin{array}{l}\text { Bank and } \\
\text { bank }\end{array}$ & Clay, & $\begin{array}{l}\text { Clay, } \\
\text { silt }\end{array}$ & Silt, & $\begin{array}{l}\text { Silt, } \\
\text { sand }\end{array}$ & $\begin{array}{l}\text { Clay, } \\
\text { sand }\end{array}$ & $\begin{array}{l}\text { Sand } \\
\text { silt }\end{array}$ & $\begin{array}{l}\text { Clay, } \\
\text { silt }\end{array}$ & $\begin{array}{l}\text { Clay, } \\
\text { silt }\end{array}$ \\
\hline toe materials & silt & gravel & gravel & Gravel & gravel & gravel & gravel & gravel \\
\hline \multicolumn{9}{|c|}{ Channel Flow Parameters } \\
\hline $\begin{array}{l}\text { Input reach } \\
\text { length }(\mathrm{m})\end{array}$ & 25.00 & 24.00 & 22.30 & 100.00 & 36.50 & 47.00 & 30.30 & 28.00 \\
\hline $\begin{array}{l}\text { Input reach } \\
\text { slope }(\mathrm{m} / \mathrm{m})\end{array}$ & 0.015 & 0.0165 & 0.007 & 0.0102 & 0.0026 & 0.004 & 0.005 & 0.0087 \\
\hline $\begin{array}{l}\text { Input } \\
\text { elevation } \\
\text { of flow }(\mathrm{m})\end{array}$ & 1.06 & 0.90 & 0.85 & 1.20 & 1.34 & 1.21 & 1.52 & 1.09 \\
\hline $\begin{array}{l}\text { Input } \\
\text { duration } \\
\text { of flow (hrs) }\end{array}$ & 12.00 & 12.00 & 12.00 & 12.00 & 12.00 & 12.00 & 12.00 & 12.00 \\
\hline $\begin{array}{l}\text { Boundary } \\
\text { shear } \\
\text { Stress }(\mathrm{Pa})\end{array}$ & 86.47 & 7.82 & 37.98 & 99.97 & 27.49 & 58.10 & 78.36 & 69.74 \\
\hline
\end{tabular}




\section{Bank stability sub model}

The bank stability sub model combines three limit equilibrium-methods to calculate a Factor of Safety (Fs) for multi-layered streambanks. The methods simulated are horizontal layers (Simon and Curini 1998, Simon et al. 2000), vertical slices for failures with a tension crack (Morgenstern and Price 1965) and cantilever failures (Thorne and Tovey 1981).

Table 4 : Geotechnical parameter input to BSTEM (after Fredlund and Rahardji 1993, Hanson and Simon 2001).

\begin{tabular}{|c|c|c|c|c|c|c|c|}
\hline \multicolumn{2}{|c|}{ Material Description } & \multicolumn{4}{|c|}{ Bank Model Input Data } & \multicolumn{2}{|c|}{ Toe Model Input Data } \\
\hline $\begin{array}{c}\text { Bank material } \\
\text { Type }\end{array}$ & $\begin{array}{l}\text { Mean grain } \\
\text { size, } D_{50}(\mathrm{~m})\end{array}$ & $\begin{array}{c}\text { Friction } \\
\text { angle } \phi\left(^{\circ}\right)\end{array}$ & $\begin{array}{c}\text { Cohesion } \\
c^{\prime}(\mathrm{kPa})\end{array}$ & $\begin{array}{c}\text { Saturated ) } \\
\text { unit weight } \\
(\mathrm{kN} / \mathrm{m} 3)\end{array}$ & $\phi^{\mathrm{b}}\left(^{\circ}\right)$ & $\begin{array}{c}\text { Critical } \\
\text { shear } \\
\operatorname{stress}(\tau)(\mathrm{Pa})\end{array}$ & $\begin{array}{l}\text { Erodibility } \\
\text { Coefficient } \\
\text { (k) }(\mathrm{cm} 3 / \mathrm{Ns})\end{array}$ \\
\hline Boulder & 0.512 & 42.0 & 0.0 & 20.0 & 15.0 & 497.66 & 0.004 \\
\hline Cobbles & 0.128 & 42.0 & 0.0 & 20.0 & 15.0 & 124.42 & 0.009 \\
\hline Gravel & 0.00113 & 36.0 & 0.0 & 20.0 & 15.0 & 10.98 & 0.030 \\
\hline Angular sand & 0.00035 & 32.3 & 0.4 & 18.5 & 15.0 & 0.25 & 0.200 \\
\hline Rounded sand & 0.00035 & 28.3 & 0.4 & 18.5 & 15.0 & 0.25 & 0.200 \\
\hline Silt & -- & 26.6 & 4.3 & 18.0 & 15.0 & 0.10 & - \\
\hline Soft clay & - & 26.4 & 8.2 & 17.7 & 15.0 & 5.00 & - \\
\hline Stiff clay & - & 21.1 & 12.6 & 17.7 & 15.0 & 50.00 & - \\
\hline
\end{tabular}

For planar failures without a tension crack, the Factor of Safety (Fs) for both the saturated and unsaturated parts of the failure plane is given by:

$$
\sum_{i=1}^{I}\left(c_{i}^{\prime} L_{i}+S_{i} \tan \varphi_{i}^{b}+\left[W_{i} \cos \beta-U_{i}+P_{i} \cos (\alpha-\beta)\right] \tan \varphi_{i}^{\prime}\right)
$$

$$
\sum_{i=1}^{I}\left[W_{i} \sin \beta-P_{i} \sin (\alpha-\beta)\right]
$$

Where,

$c_{i}^{\prime}=$ effective cohesion of $i^{\text {th }}$ layer $(\mathrm{kPa})$,

$\mathrm{L}_{\mathrm{i}}=$ length of the failure plane incorporated within the $\mathrm{i}^{\text {th }}$ layer (m),

$\mathrm{S}_{\mathrm{i}}=$ force produced by matric suction on the unsaturated part of the failure surface $\left(\mathrm{kN} \mathrm{m}^{-1}\right)$,

$\varphi^{\mathrm{b}}=$ angle representing the rate of increase in shear strength with increasing matric suction (degrees),

$\mathrm{W}_{\mathrm{i}}=$ weight of the $\mathrm{i}^{\text {th }}$ layer $(\mathrm{kN})$,

$\mathrm{U}_{\mathrm{i}}=$ the hydrostatic-uplift force on the saturated portion of the failure surface $\left(\mathrm{kN} \mathrm{m}^{-1}\right)$,

$\mathrm{P}_{\mathrm{i}}=$ the hydrostatic-confining force due to external water level $\left(\mathrm{kN} \mathrm{m}^{-1}\right)$,

$\beta=$ failure-plane angle (degrees from horizontal),

$\alpha=$ bank angle (degrees from horizontal),

$\varphi^{\prime}=$ angle of internal friction (degrees), and

$I=$ the number of layers.

The cantilever shear failure algorithm is a further development of the method employed in the CONCEPTS model (Langendoen 2000). BSTEM can utilise the different failure algorithms depending on the geometry and conditions of the bank. Determining whether a failure is planar or cantilever is based on whether there is undercutting and then comparing the factor of safety values. The failure mode is automatically determined by the smaller of the two values. The model is easily adapted to incorporate the effects of geotextiles or other bank stabilisation measures that affect soil strength. This current version (5.4) of the model assumes hydrostatic conditions below the water table. Matric suction above the water table (negative pore-water pressure) is calculated by linear interpolation.

\section{Bank toe erosion submodel}

The bank toe erosion submodel is used to estimate erosion of bank and bank toe materials by hydraulic shear stresses. The effects of toe protection are incorporated into the analysis by changing the characteristics of the toe material in the model. The model calculates an average boundary shear stress $\left(\tau_{c}\right)$ from channel geometry and flow parameters using a rectangular-shaped hydrograph defined by flow depth and the duration of the flow (steady, uniform flow). The assumption of steady, uniform flow is not critical insomuch as the model does not attempt to rout flow and sediment and is used only to establish the boundary shear stress for a specified duration along the bank surface. The model also allows for different critical shear stress and erodibility of separate zones with potentially different materials at the bank and bank toe. The bed elevation is fixed because the model does not incorporate the simulation of bed sediment transport. Toe erosion by hydraulic shear is calculated using an excess shear approach. The average boundary shear stress $\left(\tau_{\mathrm{o}}\right)$ acting on each node of the bank material is calculated using

$\tau_{\mathrm{o}}=\gamma_{\mathrm{w}} \mathrm{RS}$

Where,

$\tau_{\mathrm{o}}=$ average boundary shear stress $(\mathrm{KPa})$,

$\gamma_{\mathrm{w}}=$ unit weight of water $\left(9.81 \mathrm{kN} \mathrm{m}^{-3}\right)$, 
$\mathrm{R}=$ local hydraulic radius $(\mathrm{m})$, and

$\mathrm{S}=$ channel slope $\left(\mathrm{m} \mathrm{m}^{-1}\right)$.

An average erosion rate (in $\mathrm{m} / \mathrm{s}$ ) is computed for each node by utilizing an excess-shear stress approach (Partheniades 1965). This rate is then integrated with respect to time to yield an average erosion distance in centimeters. This method is similar to that employed in the CONCEPTS model (Langendoen 2000), except that here, erosion is assumed to occur normal to the local bank angle, and not horizontally:

$\mathrm{E}=k \Delta \mathrm{t}\left(\tau_{\mathrm{o}}-\tau_{\mathrm{c}}\right)$

Where,

$\mathrm{E}=$ erosion distance $(\mathrm{cm})$

$k=$ erodibility coefficient $\left(\mathrm{cm}^{3}(\mathrm{~N}-\mathrm{s})^{-1}\right)$,

$\Delta \mathrm{t}=$ time step $(\mathrm{s})$,

$\tau_{\mathrm{o}}=$ average boundary shear stress $(\mathrm{Pa})$, and

$\tau_{\mathrm{c}}=$ critical shear stress $(\mathrm{Pa})$.

Resistance of bank-toe and bank-surface materials to erosion by hydraulic shear is handled differently for cohesive and non-cohesive materials. Originally, for cohesive materials the relation developed by Hanson and Simon (2001) using a submerged jet-test device (Hanson, 1990; 1991) was used:

$\mathrm{k}=0.2 \tau_{\mathrm{c}}^{-0: 5}$.

The Shields (1936) criterion is used for resistance of noncohesive materials as the function of roughness and particle size (weight) and is expressed in terms of a dimensionless critical shear stress:

$\tau_{\mathrm{c}}^{*}=\tau_{\mathrm{o}} /\left[\left(\rho_{\mathrm{s}}-\rho_{\mathrm{w}}\right) \mathrm{gD}\right]$

Where,

$\tau_{\mathrm{c}}^{*}=$ critical dimensionless shear stress,

$\rho_{\mathrm{s}}=$ sediment density $\left(\mathrm{kg} \mathrm{m}^{-3}\right)$,

$\rho_{\mathrm{w}}=$ water density $\left(\mathrm{kg} \mathrm{m}^{-3}\right)$,

$\mathrm{g}=$ gravitational acceleration $\left(\mathrm{m} \mathrm{s}^{-2}\right)$, and

$\mathrm{D}=$ characteristic particle diameter $(\mathrm{m})$.

\section{RESULTS}

The BSTEM simulates the bank stability condition and bank toe erosion scenario for the streambank. Results of BSTEM for the Kodku Khola bank are summarized in Table 5. Fig. 3 shows the factor of safety for all eight transects throughout the longitudinal river profile. Results from the bank stability analysis are expressed in terms of a Factor of Safety (Fs). A value of 1.0 indicates the critical case and imminent failure; values above one are theoretically viewed as stable. However, the uncertainty and variability of soil properties and failure geometries results are such that it is considered values between 1.0 and 1.3 as conditionally stable (Simon et al. 2011). The toe erosion modeling results area eroded and lateral retreat of the bank accelerated by hydraulic erosion and geotechnical failure.

Table 5: Bank stability and toe erosion modeling results for the Kodku Khola bank.

\begin{tabular}{|c|c|c|c|c|c|c|c|c|}
\hline Transects & BK1 & BK2 & BK3 & BK4 & BK5 & BK6 & BK7 & BK8 \\
\hline \multicolumn{9}{|l|}{ Bank Model Output } \\
\hline Factor of safety $\left(\mathrm{F}_{\mathrm{s}}\right)$ & 5.89 & 3.77 & 0.75 & 0.92 & 1.17 & 4.78 & 2.60 & 0.68 \\
\hline $\begin{array}{l}\text { Conclusion } \\
(\text { Simon et al. 2011) }\end{array}$ & Stable & Stable & Unstable & Unstable & $\begin{array}{l}\text { Conditionally } \\
\text { Stable }\end{array}$ & Stable & Stable & Unstable \\
\hline Failure width (m) & 0.00 & 0.00 & 0.02 & 0.03 & 0.02 & 0.00 & 0.00 & 0.01 \\
\hline Failure volume $\left(\mathrm{m}^{3}\right)$ & 0.00 & 0.00 & 45.00 & 165.00 & 113.00 & 0.00 & 0.00 & 30.00 \\
\hline Sediment loading (tons) & 0.00 & 0.00 & 89.63 & 302.21 & 223.40 & 0.00 & 0.00 & 55.57 \\
\hline \multicolumn{9}{|c|}{ Toe Model Output (SW = GW) } \\
\hline Max. lateral retreat $(\mathrm{cm})$ & 30.59 & 116.01 & 70.83 & 208.81 & 52.88 & 65.54 & 99.99 & 53.10 \\
\hline Eroded area bank $\left(\mathrm{m}^{2}\right)$ & 0.15 & 0.35 & 0.05 & 1.62 & 0.033 & 0.02 & 0.04 & 0.15 \\
\hline $\begin{array}{l}\text { Eroded area } \\
\text { bank toe }\left(\mathrm{m}^{2}\right)\end{array}$ & 0.14 & 0.11 & 0.07 & 0.07 & 0.00 & 0.02 & 0.02 & 0.14 \\
\hline Eroded area Total $\left(\mathrm{m}^{2}\right)$ & 0.29 & 0.46 & 0.12 & 1.69 & 0.033 & 0.04 & 0.06 & 0.29 \\
\hline Shear surface elevation & 0.26 & 0.18 & 0.40 & 0.60 & 0.40 & 0.60 & 0.40 & 0.80 \\
\hline Failure angle $\left({ }^{\circ}\right)$ & 56.50 & 80.00 & 83.00 & 85.00 & 82.00 & 84.00 & 58.00 & 78.00 \\
\hline
\end{tabular}

a Abbreviations are as follows: $S W=G W$, surface water level equals groundwater level. 


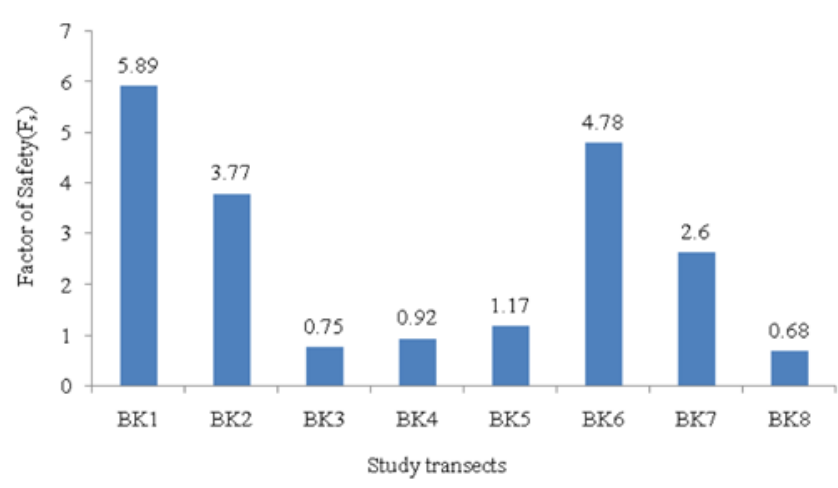

Fig. 3: Factor of safety for eight transects of the Kodku Khola.

\section{The bank model output}

The bank stability sub model calculates the $\mathrm{F}$ with failure bank width and failure volume of the sediment from particular bank. The banks of uppermost transects BK1 (Lower Badikhel) and BK2 (Upper Taukhel) are found stable where F exceeds 1.3 . The average boundary shear stress $\left(\tau_{\mathrm{o}}\right)$ acting on a bank ranges from 7.82 to $86.47 \mathrm{~Pa}$. Fig. 4 shows the stable streambank within the Transect BK2 (Upper Taukhel). While moving downstream, banks around the transect BK3 (Arubot) and the transect BK4 (Thaiba) are found unstable where $\mathrm{F}_{\mathrm{s}}$ range from 0.75 to 0.92 . Acting $\tau_{\mathrm{o}}$ on the banks ranges from 37.98 to $99.97 \mathrm{pa}$. The average volume of the sediments that had been failed from particular bank ranges from 45.00 to $165.00 \mathrm{~m}^{3}$ and the average width of the failed bank ranges from 0.02 to $0.3 \mathrm{~m}$. The load of sediment washed away from these banks ranges from 89.6 to 302.2 tons. Fig. 5 shows the unstable streambank within transect BK4 (Thaiba). Streambank of transect BK5 (Lower Thaiba), BK6 (Upper Harisiddhi) and BK7 (Lower Harisiddhi) are conditionally stable to stable where Fs range from 1.19 to 4.78 . The average boundary shear stress acting on a bank ranges from 27.49 to $78.36 \mathrm{~Pa}$. The average failure volume of the sediment is $13 \mathrm{~m}^{3}$. The load of sediment washed from particular bank is 22.34 tons. Fig. 6 shows the conditionally stable streambank of the transect BK5 (Lower Thaiba). Downstream from the Harisiddhi, the river channels have been narrowed and impaired very badly due to human encroachment and solid waste disposal. Within the transect BK8 around the Imadol area the banks are also unstable where the $\mathrm{F}_{\mathrm{s}}$ is less than 1.3.

\section{Toe model output}

The toe erosion sub model calculates the lateral and longitudinal stability of the bank toe. The bank toe of uppermost reach around the transect BK1 (Lower Badikhel) and BK2 (Upper Taukhel) area are quite stable with 0.025 $0.290 \mathrm{~m}^{2}$ of the total eroded area of bank toe and 30.59-21.86 $\mathrm{cm}$ of maximum lateral retreat of the bank. This indicates that there is less bank toe erosion hazard. Around the transects BK3 (Arubot) and BK4 (Thaiba) the bank toe are retreated more laterally indicating high degrees of channel scouring with the maximum lateral retreat of $208.81 \mathrm{~cm}$. The areas of eroded bank ranges from 0.117 to $1.695 \mathrm{~m}^{2}$ indicating excessive bank toe erosion. Within the transect BK5 Lower Thaiba), BK6 (Upper Harisiddhi) and BK7 (Lower Harisiddhi) area, the average maximum lateral retreat of the bank toeranges from 65.54 to $99.99 \mathrm{~cm}$. with average total eroded area of $0.038-0.061 \mathrm{~m}^{2}$. This shows that bank toes are less hazardous to erosion.

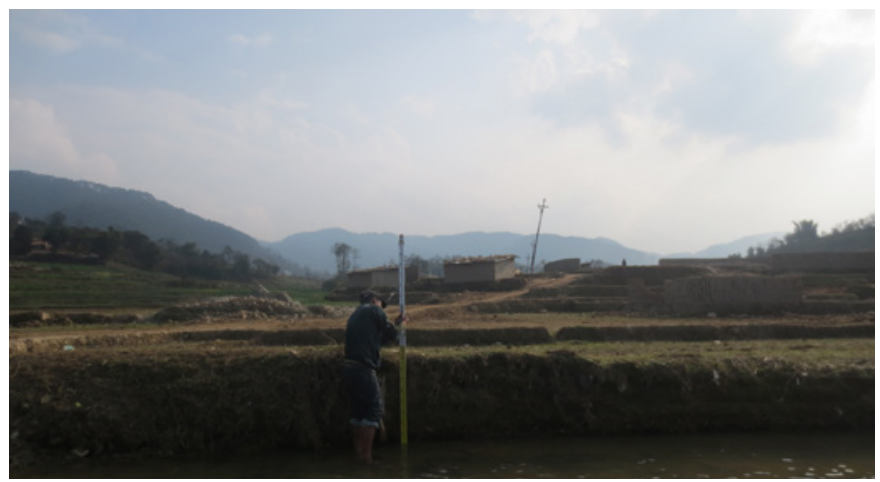

Fig. 4: Stable streambank of Transect BK 2 (Upper Taukhel).

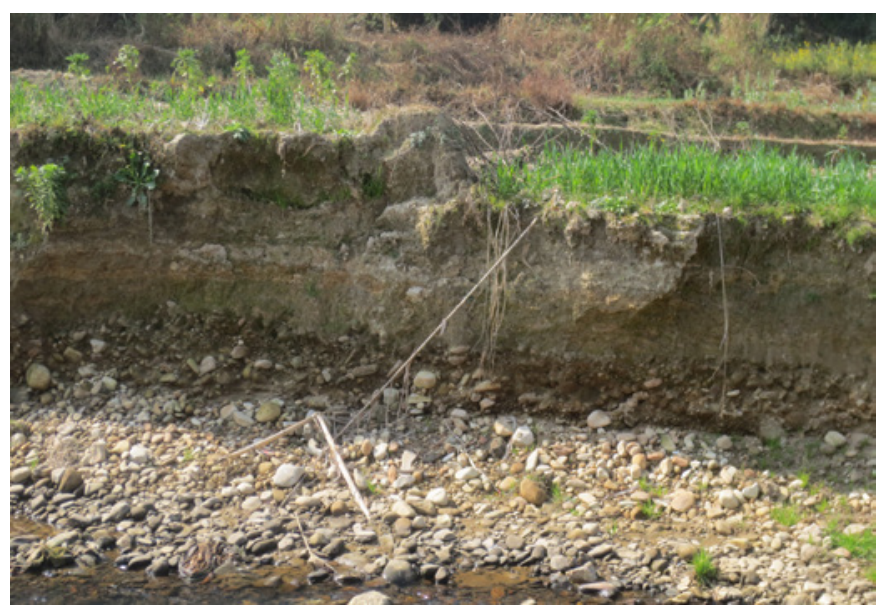

Fig. 5: Unstable streambank of transect BK4 (Thaiba).

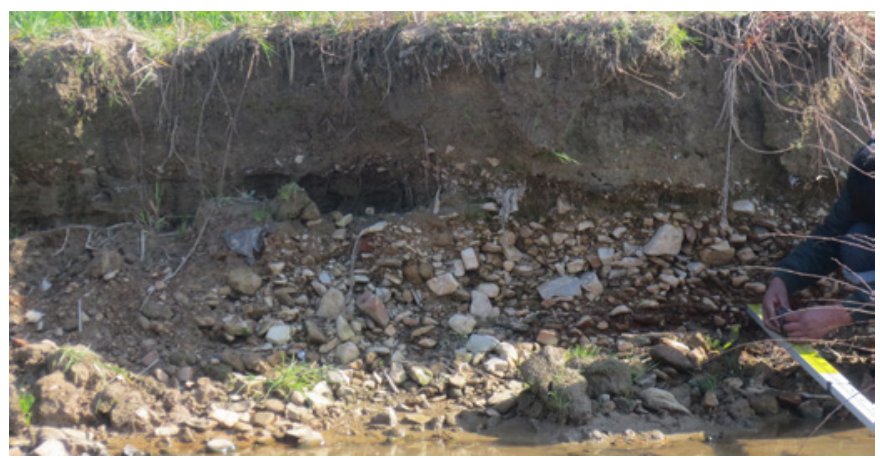

Fig. 6: Conditionally stable streambank of Transect BK5 (Lower Thaiba).

This simulation results the maximum failure volume of $165 \mathrm{cu}$. m, maximum sediment loading of 99.97 ton, maximum lateral retreat of $208.81 \mathrm{~cm}$ and maximum eroded area of 1.695 sq $\mathrm{m}$ within bank of transect BK4 (Thaiba) indicating more unstable streambank with excessive bank toe erosion. 


\section{DISCUSSION AND CONCLUSIONS}

The banks of the upper reach of the Kodku Khola around the transects BK1 (Lower Badikhel) and BK2 (Upper Taukhel) are found stable where the Fs is greater than 1.3. The canopy and understorey cover and the presence of semi- consolidated to consolidated cohesive bank materials with interlocking texture are the major causes of the bank stability. Streambank of the transect BK3 (Arubot) and BK4 (Thaiba) are unstable as Fs ranges from 0.75 to 0.92 . Major causes of instability are the presence of unconsolidated bank material, high scouring, and sparse riparian vegetation. The Thaiba segment was found more unstable and more hazardous to bank toe erosion than other segment because it has maximum failure volume of 165 cu. m, maximum sediment loading of 99.97 ton, maximum lateral retreat of $208.81 \mathrm{~cm}$ and maximum eroded area of 1.695 sq. m.

At the streambanks around the Harisiddhi area, Fs ranges from 1.19 to 4.78 which show the conditionally stable to stable stream banks. The low bank height and bank angle, low gradient with some river training activities are the causes of the bank stability.

In the Imadol area the river stretches are encroached and channelized by human and impaired badly by direct disposal of solid and liquid wastes. The river banks, where the Fs are low and banks are disturbed by encroachment, suitable bioengineering measures can be implemented to mitigate excessive bank toe erosion and failure.

\section{ACKNOWLEDGEMENTS}

The present research was partly funded by University Grant Commission (UGC) of Nepal, and authors are thankful to UGC for providing a support for carrying out this study. Supports of Mrs. Ramita Bajracharya, Mr. Prem Nath Poudel and Mr. Sudarshon Sapkota, Milan Magar during field work are highly acknowledged. Authors also thank Central Department of Geology for providing necessary facilities.

\section{REFERENCES}

Bajracharya, R., Tamrakar, N. K., Thapa, I., Sapkota, S., and Paudel, P. N., 2013, Assessment of channel stability condition of the Kodku Khola, Kathmandu basin, central Nepal Unpubl. Rreport submitted to University Grants Commission, Sanothimi, Bhaktapur, Nepal, 112 p.

Duan, J. N., 2005, Analytical approach to calculate rate of bank erosion. Jour. Hydraulic Engg., v. 131(11), pp. 980-990.

Fredlund, D. G. and Rahardjo, H., 1993, Soil Mechanics of Unsaturated soils, John Wiley \& Son Inc., New York, $544 \mathrm{p}$.

Hanson, G. J., 1990, Surface erodibility of earthen channels at high stresses: Part II. Developing an in-situ testing device, Trans. ASAE, v. 33(1), pp, 132-137.

Hanson, G. J., 1991, Development of a Jet index to characterize erosion resistance of soils in earthen spillways, Trans. ASAE, 34(5), pp, 2015-2020.
Hanson, G. J. and Simon, A., 2001. Erodibility of cohesive streambeds in the loess area of the midwestern USA, Hydrol. Processes, v. 15(1), pp. 23-38.

Hoek, E. and Bray, J. D., 1981, Rock Slope Engineering. 3rd ed. CRC Press, 368 p.

Langendoen, E. J., 2000, CONCEPTS: Conservational channel evolution and pollutant transport system software manual, Res. Rep. 16, Natl. Sediment. Lab., Argic. Res. Serv., US Dept. Agri., Oxford, Miss. Mining and Metallurgy, $402 \mathrm{p}$.

Morgenstern, N. R. and Price, V. E., 1965, The analysis of the stability of general slip surfaces. Geotechnique, v. 15(1), pp. $79-93$.

Partheniades, E., 1965, Erosion and deposition of cohesive soils, Jour. Hydraulic Engg., v. 91(1), pp. 105-139.

Shields, A., 1936, Application of similarity principles and turbulent research to bed-load movement. In: W. P. Ott and J. C. Uchelen (translators), Mitt. Preuss, Verschsanst., Berlin. Wasserbau Schifbau. California Institute of Technology, Pasadena, CA, Report No. 167, 43 p.

Simon, A. and Curini, A., 1998, Pore pressure and bank stability: The influence of matric suction, in Water Resources Engineering '98 (eds. S. R. Abt, J. YoungPezeshk, and C. C. Watson), Am. Soc. of Civ. Eng., Reston, VA, pp. 358-363.

Simon, A., Curini, A., Darby, S. E. and Langendoen, E. J., 1999, Stream-bank Mechanics and the Role of Bank and Near-Bank Processes in Incised Channels. In: Darby, S. and Simon, A., eds. Incised River Channels. John Wiley and Sons, New York, pp. 123-152.

Simon, A., Curini, A., Darby, S. E., and Langendoen, E. J., 2000, Bank and near-bank processes in an incised channel. Geomorphology, v. 35, pp, 183-217.

Simon, A., Pollen-Bankhead, N. and Thomas, R. E., 2011, Development and application of a deterministic bank stability and toe erosion model for stream restoration. In: Stream Restoration in Dynamic Fluvial Systems (Eds: A. Simon, S. J. Bennett and J. M. Castro), American Geophysical Union, Washington, D. C. doi: 10.1029/2010GM001006.

Stöcklin J., 1980, Geology of Kathmandu area and central Mahabharat range, Nepal Himalaya, HMG-UNDP, Mineral exploration project, Kathmandu Nepal.

Tamrakar, N. K., Bajrachrya, R., Thapa, I., Sapkota, S, and Paudel P. N., 2013, Morpho-hydrologic parameters and classification of the Kodku Khola for stream stability assessment, southern Kathmandu, Central Nepal. Bull. Dept. Geol., v. 16, pp. 1-20.

Thorne, C. R. and Tovey, N. K., 1981, Stability of composite river banks. Earth Surface. Processes Landforms, v. 6, pp. 469-484.

Yoshida, M. and Igarashi, Y., 1984. Neogene to Quaternary lacustrine sediments in the Kathmandu Valley, Nepal. Jour. Nepal Geol. Soc., v. 4 (Sp. Issue), pp. 73-100. 